\title{
BURUH VS PERUSAHAAN (Studi Kasus Konflik Buruh/Pekerja Driver Go-Jek dengan PT Go-Jek Indonesia)
}

\author{
$\operatorname{Randi}^{1}$
}

\begin{abstract}
ABSTRAK
Perkembangan serikat buruh di Indonesia sangat pesat. Tentunya perkembangan tersebut tidak terlepas dari tumbuhnya perusahaan-perusahaan besar di Indonesia. Dengan perkembangan tersebut jumlah buruh semakin meningkat dan hak-hak buruh semakin perlu diperhatikan baik oleh pemerintah, perusahaan maupun oleh organisasi buruh itu sendiri. Adapun fokus dalam tulisan ini, akan membahas bagaimana konflik buruh driver gojek dengan PT Go-Jek yang berbasis teknologi terjadi, dan katup pengaman dalam konflik tersebut. Sebab untuk mempertahankan struktur sosial dalam perusahaan dibutuhkan "win win solution". Sebagaimana Coser menjelaskan bahwa konflik dapat mempertahankan atau membentuk strutur sosial baru, dan katup pengaman berperan sebagai peredam konflik diantara dua pihak, konflik yang terjadi antara buruh/pekerja dengan perusahaan pada masa industrial. Analisis konflik yang terjadi antara buruh driver gojek dengan PT Go-Jek, ada tiga tuntutan buruh/pekerja terhadap PT Go-Jek, yaitu pengembalian tarif ke harga semula, diangkat menjadi karyawan, dan transparansi dana.
\end{abstract}

Kata Kunci : Buruh, driver, Go-Jek, konflik, perusahaan

\begin{abstract}
Growth of labour union in Indonesia very fast. It is of course the growth is not quit of the growing of big companys in Indonesia. With growth is amount of labour progressively mount and labour rights progressively require to be paid attention either by government, company and also by itself labor organization. As for focus in this article, will study how labour conflict of driver gojek with PT Go-Jek being based on technology happened, and safety valve in conflict. Cause to maintain social structure in company required "win win solution". As Coser explain that conflict can maintain or form social strutur newly, and safety valve personate silencer of conflict between two side, conflict that happened between labour/worker with company at a period of industrial. Conflict analysis that happened between labour of driver gojek with PT Go-Jek, there is three labour demand/worker to PT Go-Jek, that is return of tariff to price initialy, lifted to become employees, and fund transparency.
\end{abstract}

Keyword : Labour, driver, Go-Jek, conflict, company

\section{PENDAHULUAN}

Buruh adalah bagian dari masyarakat yang perlu disejahterakan secara sosial, politik, budaya dan ekonomi. Keberadaan buruh di Indonesia sudah ada semenjak zaman penjajahan Belanda. Sedangkan pergerakan buruh semenjak 1897, yaitu serikat buruh guru-guru bangsa Belanda di Indonesia. Serikat peerja tersebut adalah NIOG (Nederland Indies Onderw Genooth). Berdirinya serikat buruh tersebut tidak terlepas dari perkembangan pergerakan buruh di Nederland tahun 1860-1870.
Pergerakan itu semakin berkembang dan dibentuklah National Arbeids Secretariaat (NAS) tahun 1978. Tumbuhnya gerakan buruh di Nusantara dibawah oleh pegawai Belanda pada saat itu (Sandra, 2007). Sejarah kolonianisme di Indonesia sangat berdampak terhadap kehidupan sosial, ekonomi masyarakat, terutama dalam hal sistem kerja di Indonesia.

Pergerakan buruh di Indonesia yang diinisiasi oleh pribumi pada tahun 18971907, tetapi yang menjadi perbedaan dengan serikat buruh di Nederland yaitu belum

\footnotetext{
${ }^{1}$ Mahasiswa Pascasarjana, Program Studi Sosiologi, Fakultas Ilmu Sosial dan Ilmu Politik, Universitas Padjadjaran, Bandung.
} 
adanya pemimpin untuk menyalurkan keinginannya. Pada tahun 1908 timbul kesadaran buruh Indonesia untuk melakukan pergerakan. Pergerakan buruh Indonesia didasarkan atas kebangkitan nasional yang dipelopori oleh Budi Utomo. Kebangkitan nasional tersebut bertujuan untuk melepaskan diri dari kolonialisme di Indonesia. Sehingga pergerakan buruh tersebut tidak lepas dari peran partai politik. Partai politik yang berperan dalam mengembangkan pergerakan buruh yaitu; pertama, Serikat Islam (1912), yang memiliki pengaruh sangat besar di masyarakat. Kedua, Social Democratische Vereniging (1914) yang didirikan oleh orang Belanda dari Social Democratische Party (Sandra, 2007).

Adapun organisasi buruh di Indonesia yaitu Dewan Serikat Buruh Indonesia (DSBI) tahun 1952 anggotanya GSBI, PSBI, dan GOSBU, Himpunan Serikat Buruh Indonesia (HISSBI) tahun 1952, Konsentrasi Buruh Kerakyatan Indonesia (KBKI) tahun 1952, tahun 1953 Kongres Burug Seluruh Indonesia (KBSI) yang terdiri dari depalan anggota, Serikat Buruh Muslim Indonesia yang di prakarsai Nahdhatul Ulama (NU) akhir tahun 1955, Sentral Organisasi Buruh "Panca sila" tahun 1957, Gerakan Organisasi Buruh Serikat Islam (GOBSII) tahun 1955, Kongres Buruh Islam Merdeka (KBIM) tahun 1956 (Sandra, 2007). Keberadaan buruh dimasa lampau sangat penting, dimana menjadi cikal bakal perkembangan buruh di Indonesia.

Setelah reformasi perkembangan buruh semakin meningkat, banyak sudah serikat buruh yang terbentuk. Keinginan para buruh di Indonesia untuk dapat sejahtera dan dapat bekerja dengan baik di perusahaan tempat mereka bekerja, sehingga buruh sering kali melakukan aksi. Banyak demonstrasi yang dilakukan para serikat buruh indonesia diantara meminta naik gaji, tunjangan, jaminan kesehatan dan waktu cuti.
Berikut enam serikat buruh atau konfederasi menurut catatan Direktorat Kelembagaan dan Kerjasama Hubungan Industrial Kementerian Tenaga Kerja RI yang dirilis pada akhir tahun 2015, yaitu Kongres Aliansi Serikat Buruh Indonesia (KASBI) berada hanya di wilayah DKI Jakarta sebagian di Jawa Barat dan Jawa Tengah, Konfederasi Serikat Buruh Seluruh Indonesia (KSBDSI) berada di 22 provinsi dengan 28 federasi yang tersebar diberbagai daerah terutama di wialayah Indonesia Timur, Konfederasi Serikat Buruh Sejahtera Indonesia (KSBSI), Konfederasi Serikat Nasional (KSN), Konfederasi Serikat Pekerja Indonesia (KSPI) dan Konfederasi Serikat Pekerja Seluruh Indonesia (KSPSI) (Ereste, 2016).

Serikat buruh juga seringkali di kendalikan oleh pemerintah dengan tujuan untuk mencanangkan industrialisasi, diamana adanya peraturan pemerintah hanya ada satu serikat saja di Indonesia yang diakui yaitu Serikat Pekerja Seluruh Indonesia (SPSI). Dengan adanya peraturan tersebut membuat buruh tidak bebas membentuk serikat sesuai dengan keinginanannya, sehingga sulit untuk menyuarakan kepentingan buruh (Purwaningsih, 2008). Peraturan yang telah dibuat pemerintah belum dapat dilakukan sepenuhnya, karena perusahaan memliki kepentingan untuk mendapatkan keuntungan yang sebesarbesarnya sesuai dengan keinginan pemilik modal (Novius, 20017). Kepentingan perusahaan tidak terlepas dari kewajibannya sebagai tempat bekerja buruh, dimana perusahaan memberikan mensejahterakan buruh/pekerja dengan memberikan gaji, pelayanan, cuti, perlindungan dan pemberian bonus kerja. Hal tersebut sangat penting dilakukan oleh perusahaan untuk meningkatkan semangat kerja buruh/pekerja, sehingga produksi akan berjalan dengan baik sesuai keinginan perusahaan.

Dari uraian diatas penulis tertarik menganalisis konflik buruh/pekerja dengan 
perusahaan, yaitu konflik buruh driver gojek dengan PT Go-Jek Indonesia. PT Go-jek adalah perusahaan yang berbasis teknologi yang bertujuan untuk meningkatkan kesejahteraan pekerja atau buruh yang bekerja di sektor informal di Indonesia dan berdampak sosial. PT Go-Jek adalah perusahaan yang sudah tersebar di beberapa wilayah di Indonesia, diantaranya Jakarta, Palembang, Makassar, Medan, Yogyakarta, Bandung, Bali, Surabaya, Semarang, dan Balikpapan. Sudah banyak pekerja atau buruh yang mereka miliki yaitu sekitar 200.000 pengendara ojek yang sudah di training dan terpercaya di Indonesia. Fungsi dan tugas buruh ini adalah memberikan pelayanan transportasi, antar pesan makanan. Ada beberapa pelayanan yang diberikan oleh perusahaan PT Go-Jek kepada masyarakat yaitu Go-Ride, Go-Car, Go-Massage, GoFood, Go-Clean, Go-box, dan Go-Mart, GoPulsa, Go-Aut0, Go-Busway, Go-Tix, GoSend, Go-Glam, dan Go-Med. Dalam memberikan pelayanan Gojek berdasarkan kepada tiga nilai utama yaitu: kecepatan, inovasi, dan dampak sosial. Setiap buruh yang bekerja di PT gojek ini medapatkan santunan kesehatan, kecelakaan dan mendapatkan akses lebih ke pelanggan melalui aplikasi yang telah dibuat oleh PT Go-Jek. (www.metro.news.viva.co.id, 2016).

Dalam konflik antara buruh driver gojek dengan PT Go-Jek, peran pemerintah belum hadir sebagai lembaga atau katup pengaman, sehingga konflik tersebut akan tetap berlanjut dan merugikan para pekerja dan perusahaan. Hal inilah yang membuat penulis tertarik untuk menganalisis konflik tersebut dengan pendekatan teori Lewis C. Coser. Coser mengatakan bahwa konflik memiliki peran dalam mempertahankan struktur sosial dalam masyarakat. Coser memandang bahwa konflik yang terjadi tidak selalu berdampak difungsi tetapi dengan konflik tersebut, akan menjaga dan bahkan melakukan perubahan baru dalam struktur sosial. Penulis merasa bahwa konflik yang terjadi antara buruh driver gojek dengan PT Go-Jek adalah wujud dari konflik yang akan memperkuat stuktrur sosial dalam PT. GoJek tersebut. Sedangkan negara sebagai katup pengaman hendaknya hadir di tengah-tengah konflik yang terjadi, dan meredam konflik. Namun pada kenyataan negara belum hadir pada saat konflik terjadi, hadirnya sebagai katup pengaman, penulis merasa negara sebagai lembaga yang berwenang belum berfungsi sebagaimana mestinya.

Adapun penelitian terdahulu yang berkaitan dengan analisis yang akan dilakukan oleh penulis yaitu Konflik Industrial (Suatu Kajian Kritis Terhadap Konflik Industrial) (Sutinah, 2011). Konflik industrial secara realitas selalu terjadi dimasyarakat. Analisis menggunakan pendekatan teori konflik dari Marx, Marx mengatakan bahwa dalam relasi reproduksi ada pemilik modal dan buruh. Dari kedua kelompok masyarakat industri tersebut menghasilkan profit bagi pemilik modal dan eksploitasi kaum buruh. Sehingga sistem penguasaan sistem capital. Adanya hubungan anatara buruh dan pemilik modal sehingga terjadinya konflik sosial masyarakat dan eksploitasi di kaum buruh itu sendiri. Kemudian penelitian yang dilakukan Idi Setyo Utomo dengan judul Suatu Tinjauan Tentang Tenaga Kerja Buruh di Indonesia). Dalam artikel ini permasalahan yang dihadapi oleh para pekerja buruh di Indonesia, dimana hubungan yang harmonis antara unsur pengusaha dan unsur pekerja/buruh, peran aktif dan positif lembaga kerja sama bipartit sangat penting untuk terjalinnya hubungan industrial yang berkelanjutan dan setiap permasalahan dapat diselesaikan oleh lembaga bipartit dengan pemecahan didsasrkan pada "win-win solution" (Utomo, 2005). Yang membedakan dengan penelitian terdahulu bahwa dalam analisis konflik antara buruh driver gojek dengan PT Go-Jek bahwa 
konflik yang terjadi sebagai penguatan internal PT Go-Jek dan dianalisis dengan pendekatan teori Lewis C. Coser.

\section{PEMBAHASAN}

\section{Realitas Hubungan Buruh Driver Go-Jek} dan PT Go-Jek dalam Undang-Undang

Hubungan yang terjalin antara buruh dengan perusahaan telah diatur dalam Undang-Undang Republik Indonesia No.13 tahun 2003 dalam pasal 1 mengatakan bahwa (15) Hubungan kerja adalah hubungan antara pengusaha dengan pekerja/buruh berdasarkan perjanjian kerja, yang mempunyai unsur pekerjaan, upah, dan perintah. (16) Hubungan industrial adalah suatu sistem hubungan yang terbentuk antara para pelaku dalam proses produksi barang dan/atau jasa yang terdiri dari unsur pengusaha, pekerja/buruh, dan pemerintah yang didasarkan pada nilai nilai Pancasila dan Undang Undang Dasar Negara Republik Indonesia Tahun 1945. Setiap perusahaan tentunya memiliki hubungan dengan buruh yang mereka pekerjakan, sebab dengan adanya keberadaan buruh tersebut perusahaan dapat berkembang dan tumbuh menjadi besar. Seperti PT Go-Jek yang sekarang sudah menjadi perusahaan yang besar di Indonesia yang berabasis internet. Realitas hubungan buruh driver gojek dengan PT Go-Jek yaitu hubungan antara buruh driver gojek dengan perusahaan telah diatur dalam Undang-Undang tersebut, dimana perusahaan memberikan hak-hak buruh sebagai driver gojek, sedangkan buruh memberikan kewajibannya kepada perusahaan yaitu pelayanan yang diinginkan oleh perusahaan. Menurut Undang-Undang No. 21 tahun 2000 tentang serikat pekerja /serikat buruh, Bab VI pasal 25 mengatakan bahwa Hak dan Kewajiban buruh sebagai berikut:

(1) Serikat pekerja/serikat buruh, federasi dan konfederasi serikat pekerja/serikat buruh yang telah mempunyai nomor bukti pencatatan berhak:

a. membuat perjanjian kerja bersama dengan pengusaha;

b. mewakili pekerja/buruh dalam menyelesaikan perselisihan industrial;

c. mewakili pekerja/buruh dalam lembaga ketenagakerjaan;

d. membentuk lembaga atau melakukan kegiatan yang berkaitan dengan usaha peningkatan

e. kesejahteraan pekerja/buruh;

f. melakukan kegiatan lainnya di bidang ketenagakerjaan yang tidak bertentangan dengan peraturan perundang-undangan yang berlaku.

Dalam Undang-Undang tersebut sebagai acuan buruh driver gojek dalam memenuhi hak-haknya sebagai pekerja di PT Go-Jek, sehingga adanya keinginan dari para buruh driver gojek untuk membentuk serikat buruh gojek, dengan tujuan untuk meminta kejelasan terhadap PT Go-Jek. Walaupun secara resmi belum terbentuk serikat buruh gojek, tetapi buruh driver gojek ini perlu di lindungi hak-haknya baik perlindungan hukum dan kesejahtraan buruh driver gojek, sehingga perlu disamakan keberadaannya dengan buruh-buruh lain di persuahaan. Sesuai dengan Undang-Undang No. 40 tahun 2007 tentang perseroan terbatas dalam pasal 1 (3) bahwa tanggung Jawab Sosial dan Lingkungan adalah komitmen Perseroan untuk berperan serta dalam pembangunan ekonomi berkelanjutan guna meningkatkan kualitas kehidupan dan lingkungan yang bermanfaat, baik bagi Perseroan sendiri, komunitas setempat, maupun masyarakat pada umumnya. Berdasarkan UndangUndang tersebut,per usahaan berhak untuk meningkatkan kesejahteraan pekerja. Setiap peraturan yang dibuat oleh pemerintah tentunya dengan pertimbangan dan tujuan tersendiri, diantaranya untuk meningkatkan 
kesejahteraan masyarakat. Pihak swasta pun memiliki tanggung jawab terhadap kesejahteraan masyarakat, mengingat perusahaan melakukan produksi dan menjualnya baik produk maupun jasa.

\section{Konflik Buruh Driver Go-jek dengan PT Go-Jek}

Konflik yang terjadi antara driver gojek dan perusahaan berawal dari aksi mogok yang dilakukan oleh driver gojek, hal ini terjadi karena beberapa alasan, adanya hak-hak buruh driver gojek belum terpenuhi seperti yang dilansir dalam (www.metro.news.viva.co.id, 2016) bahwa status kemitraan yang berjalan selama ini antara buruh driver gojek dengan PT Go-Jek telah melanyalahi Undang-Undang Nomor 13 tahun 2003 tentang Ketenagakerjaan. Adapun tuntutan buruh driver gojek kepada PT Go-Jek, yaitu; pertama, adanya keinginan dari buruh driver gojek untuk meminta diangkat menjadi karyawan, sebab menurut mereka hal tersebut terkait dengan pemotongan gaji yang jelas, kedua, pengembalian ke tariff awal yaitu Rp. 4.000 yang sebelumnya diturunkan menjadi Rp. 3.000, hal tersebut dianggap merugikan buruh driver gojek secara pendapatan ekonomi, dan permintaan ini telah ditolak oleh PT Go-Jek, ketiga, menyangkut transparansi PT Go-Jek terhadap buruh driver gojek, tidak transparansinya perusahaan akan memunculkan tanda tanya terhadap perusahaan sendiri. Kemudian menurut buruh driver gojek bahwa PT GoJek telah melanggar Undang-Undang Nomor 13 tahun 2003 tentang Ketenagakerjaan. Dari peristiwa tersebut menimbulkan aksi atau demonstrasi oleh buruh driver gojek di depan PT Go-Jek. Walaupun sudah dimediasi antara kedua bela pihak tetapi masih belum menemukan jalan atau solusi yang terbaik, perundingan selalu mengalami kebuntuan (Fenwick, Lindsey, \& Arnold, 2002), kebuntuan yang dialami dalam penyelesaian konflik tersebut diakibatkan kedua bela pihak belum ada yang mau mengesampingkan kepentingan masing-masing. Tentunya hal ini akan menimbulkan konflik didalam tubuh PT Go-Jek, dan akan mengganggu struktur sosial dalam PT Go-Jek, kemudian akan menghambat setiap proses pelayanan PT GoJek kepada buruh driver gojek.

Kemudian hal yang paling terpenting adalah pelayanan kepada konsumen PT GoJek akan terhambat, dan akan menyebabkan kerugian bagi perusahaan. Aksi pemogokkan yang dilakukan oleh buruh driver gojek adalah bentuk protes buruh terhadap perusahaan dan dari protes tersebut menjadikan pelayanan yang diberikan kepada masyarakat akan terhambat. Menurut Undang-Undang No. 21 tahun 2000 bahwa perselisihan antar serikat pekerja/antar serikat buruh, federasi dan konfederasi serikat pekerja/serikat buruh adalah perselisihan antara serikat pekerja/serikat buruh, federasi dan konfederasi serikat pekerja/serikat buruh, dan serikat pekerja/serikat buruh, federasi dan konfederasi serikat pekerja/serikat buruh lain, karena tidak adanya persesuaian paham mengenai keanggotaan serta pelaksanaan hak dan kewajiban ke serikat pekerjaan.

Berdasarkan kasus tersebut ada beberapa hak buruh belum terpenuhi secara baik oleh perusahaan atau PT Go-Jek, sehingga adanya keinginan dari para mitra kerja untuk membentuk serikat, adapun tujuan serikat tersebut yaitu: (1) untuk melindungi anggotanya, membela hak dan kewajiban, dan kesejahteraan pekerja maupun keluarganya, (2) tujuan tersebut tidak dapat tercapai apabila perusahaan tempat para pekerja dipekerjakan secara tidak produktif, sehingga pekerja diharapkan pula menyumbang pada peningkatan kinerja perusahaan, sehingga kesejahteraan pekerja akan menigkat (ILO, 2002). Menurut tujuan serikat tersebut keinginan buruh driver gojek adalah salah satu bentuk untuk mencapai 
tujuan buruh driver gojek itu sendiri yaitu untuk kesejahteraan para anggota buruh driver gojek. Sedangkan sesuai dengan visi dan misi PT Go-Jek untuk yaitu kecepatan, inovasi, dan dampak sosial, dampak sosial disini, salah satunya adalah kesejahteraan sosial bagi para buruh driver gojek. Sudah selayaknya perusahaan memberikan dampak sosial lebih besar kepada buruh.

Dalam teori hubungan industrial bahwa adanya konflik kepentingan yang besifat bawaan antara perusahaan dengan pekerja. Teori ini juga mengakui kesamaan kepentingan antara pengusaha dengan pekerja. Sebab upaya mencapai hubungan industrial yang harmonis hendaknya didasarkan atas kesamaan kepentingan tersebut dan menjebatani perbedaan kepentingan yang akan menimbulkan konflik (Ghosh, 2002). Sama halnya yang terjadi dengan buruh driver gojek dan PT Go-Jek persamaan keinginan yaitu untuk mendapatkan keuntungan. Tetapi pada kenyataan kepentingan tersebut belum terpenuhi oleh kedua bela pihak. Meski adanya nilai-nilai yang bekerja sebagai katup pengaman sudah dilaksanakan yaitu mediasi, tetapi masih belum memberikan solusi yang terbaik, sehingga buruh driver akan melakukan demonstrasi lagi.

Menurut pandangan kaum fungsionalis bahwa konflik adalah disfungsional bagi suatu kelompok. Maka Coser memandang berbeda, konflik dapat merupakan proses yang bersifat instrumental dalam pembentukan, penyatuan dan pemeliharan struktur sosial. Konflik dapat menetapkan dan menjaga garis batas antara dua atau lebih kelompok. Konflik dengan kelompok lain dapat memperkuat kembali identitas kelompok dan melindunginya agar tidak lebur ke dalam dunia sosial sekelilingnya. Strutural konflik yang dikemukakan oleh Coser, bahwa untuk memepertahankan struktural tersebut melalui konflik. Coser memilih menunjukkan berbagai sumbangan konflik yang secra potensial positif untuk membentuk serta mempertahankan struktur (Poloma, 2007). Dimana konflik adalah satu keharusan yang terjadi dalam satu struktur sosial. Kritik terhadap teori coser bahwa sudah dapat dengan jelas dapat ditebak dan tidak diragukan lagi bahwa untuk menjaga structural tersebut dengan konflik itu sendiri, sehingga ada satu katup pengaman dalam konflik itu. Coser mengembangkan perspektif konflik karya ahli sosiologis Jerman George Simmel, Simmel mengatakan bahwa konflik merupakan bentuk interaksi dimana tempat, waktu serta intensitas dan lain sebagainya tunduk pada perubahan, sebagaimana dengan isi segitiga yang dapat berubah atau dengan kata lain simmel memandang pertikaian sebagai gejala yang tidak mudah untuk dihindari dalam masyarakat dan memandang pertikaian sebagai gejala yang tidak mungkin dihindari dalam masyarakat kemudian Struktur sosial dipandang sebagai gejala dari proses asosiatif dan disosiatif yang tidak mungkin terpisahpisahkan, tetapi dapat dianalisis secara berbeda. Dari pernyataan teori tersebut Coser mengembangkan proposisi dan memperluas konsep Simmel tersebut dalam menggambarkan kondisi-kondisi dimana konflik secara positif membantu struktur sosial dan bila terjadi secara negatif akan memperlemah kerangka masyarakat dan jika dipandang secara positif akan mempertahankan atau membuat baru struktur sosial tersebut (fungsionalitas konflik bagi kelompok sosial).

\section{Negara sebagai Katup pengaman (Safety Valve) konflik Buruh Driver Gojek dengan PT Go-Jek}

Menurut Coser katup pengaman bertujuan untuk mempertahankan stuktur sosial. Katup pengaman atau safety valve merupakan salah satu mekanisme khusus yang digunakan untuk mempertahankan 
kelompok dari konflik sosial yang disalurkan dari lembaga-lembaga atau nilai, norma yang ada diantara kedua bela pihak. Dimana adanya pembiaran luapan permusuhan untuk menghancurkan seluruh struktur atau dengan kata lain membantu membersihkan suasana dalam kelompok yang sedang kacau. Coser melihat katup pengaman berfungsi sebagai jalan ke luar yang meredakan permusuhan, dan tanpa katup pengaman tersebut hubungan- hubungan di antara pihak-pihak yang bertentangan akan semakin menajam. Sebagaimana yang dinyatakan oleh Coser; lewat katup pengaman itu, permusuhan dihambat agar tidak berpaling melawan obyek aslinya. Tetapi penggantian yang demikian mencakup juga biaya bagi sistem sosial maupun bagi individu, mengurangi tekanan untuk menyempurnakan sistem untuk memenuhi kondisi-kondisi yang sedang berubah maupun membendung ketegangan dalam diri individu, menciptaan kemungkinan tumbuhnya ledakan-ledakan destruktif. Dalam mediasi Jokes atau lelucon yang diselipkan dalam situasi tegang dapat juga mengurangi atau menghilangkan ketegangan yang terjadi, sekalipun lelucon tersebut sebagai sebuah kritik. Tetapi dalam media kedua bela pihak antara buruh driver gojek dengan PT Go-Jek tidak menggunakan jokes tersebut. Sehingga ketegangan belum terselesaikan.

Menurut analisis konflik tersebut katup pengaman (safety valve) yang tepat adalah lembaga negara. Konflik yang terjadi antara buruh driver gojek dengan PT Go-Jek adalah salah satu bentuk konflik industrial. Keterlibatan negara dalam membentuk peraturan-peraturan ketenagakerjaan dirsa sangat tepat. Konflik yang terjadi karena suatu produksi baik komoditi ataupun jasa. Dalam hal ini konflik pelyanan yang diberikan oleh PT Go-Jek belum memuaskan buruh/pekerja. Dalam menyelesaikan konflik berarti konflik tersebut harus berakhir, sehingga kedua bela pihak yang terlibat dalam konflik tersebut dengan lapang dada bersedia menerima dan mematuhi setiap keputusan atau upaya yang diberikan untuk penyelesaian konflik, dan konflik tersebut benar benar selesai (ILO, 2002).

Negara sebagai lembaga yang memiliki wewenang dan pembuat setiap kebijakan memberikan sosialisasi tentang kebijakan tersebut, melalui tealitas konflik antara buruh driver gojek dengan PT Go-Jek, sebab jika konflik tersebut hanya diselesaikan oleh kedua bela pihak sulit ditemukan win-win solution. Karena setiap solusi yang diberikan syarat akan kepentingan masing-masing. Tentunya buruh driver gojek menginginkan untuk diangkat menjadi karyawan, menaikkan tarif harga setiap tarikan atau pelayanan yang diberikan oleh buruh driver gojek kepada konsumen, sedangkan PT Go-Jek pun menginginkan sebaliknya dengan pertimbangan perusahaan. Sehingga akan sulit ditemukan solusi yang terbaik dan tidak merugikan kedua bela pihak.

\section{KESIMPULAN}

Dari uraian diatas dapat disimpulkan bahwa konflik yang terjadi antara buruh driver gojek dengan perusahaan adalah konflik yang berdampak terhadap stuktur sosial perusahaan PT Go-Jek, yaitu pelayanan dan pemerian upah buruh driver gojek. Sebagai perusahaan yang berbasis teknologi sudah seharusnya perusahaan menjaga struktur sosial yang baik antara buruh driver gojek dengan perusahaan, dengan tujuan terjalin hubungan yang harmonis antara buruh dan perusahaan. Sehingga dengan hubungan yang harmonis tersebut akan terwujudnya pelayanan yang cepat, inovasi dan berdampak sosial. Konflik bukan semata menimbulkan perpecahan tetapi menguatkan struktur yang ada di PT Go-Jek itu sendiri.

Dalam memberikan pelayanan kepada masyarakat sudah selayaknya PT Go- 
Jek memberikan kenyamanan kepada mitra kerja atau buruh/pekerja driver gojek. Dengan kenyamanan tersebut tidak akan terjadinya konflik yang berarti dan berdampak terhadap perusahaan. PT Go-Jek pun harus menjaga kredibilitasnya sebagai perusahaan yang berbasis teknologi, yang memberikan pelayanan kepada masyarakat.

\section{DAFTAR PUSTAKA}

\section{Buku:}

Fenwick, C., Lindsey, T., \& Arnold, L. (2002). Reformasi Penyelesaian Perselisihan Perburuan di Indonesia. Jakarta: ILO.

Ghosh, A. (2002). Buku Pegangan Pelatih (Hubungan Industrial dan Kerjasama Tempat Kerja). Jakarta: ILO.

ILO. (2002). Buku Panduan Undang-undang Serikat Buruh/Serikat Pekerja Indonesia (UU No. 21/2000). Jakarta: Kantor Perburuhan Internasional.

Poloma, M. M. (2007). Sosiologi Kontemporer. Jakarta: PT RajaGrafindo Persada.

Sandra. (2007). Sejarah Pergerakan Buruh Indonesia. Jakarta: TURC.

Sutinah. (2011). Konflik Industrial (Suatu Kajian Kritis Terhadap Konflik Industrial). Surabaya: $\quad$ FISIP Universitas Airlangga.

\section{Jurnal}

Ereste, E. J. (2016, Februari Kamis). Data Keanggotaan Organisasi Buruh Indonesia di Kemenaker RI Tidak Akurat. pp. 1-4 .

Novius, A. (20017). Fenomena Kesejahteaan Buruh/Karyawan Perusahaan Di Indonesia (Phenomenon Employee/Laborer's Benefit in Indonesian Corporates). Fokus Ekonomi, Vol. 2, 8191.

Purwaningsih, R. (2008). KONFLIK ANTAR SERIKAT BURUH. Jurnal Bisnis dan Ekonomi (JBE), 143-148.
Utomo, I. S. (2005). Suatu Tinjauan Tentang Tenaga Kerja Buruh di Indonesia. Journal The WINNERS, , 84 Vol. 6 No. $1,: 83-93$.

Undang-Undang

Undang-Undang No. 40 tahun 2007 tentang perseroan terbatas

Undang-Undang No. 21 tahun 2000 tentang serikat pekerja /serikat buruh

Undang-Undang Nomor 13 tahun 2003 tentang Ketenagakerjaan

\section{Web Resmi}

www.metro.news.viva.co.id. (2016). 